Consiglio Nazionale delle Ricerche
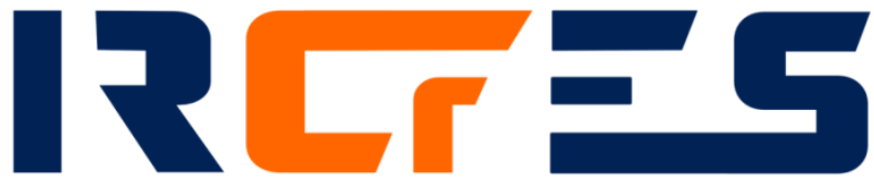

ISTITUTO DI RICERCA SULLA CRESCITA ECONOMICA SOSTENIBILE RESEARCH INSTITUTE ON SUSTAINABLE ECONOMIC GROWTH
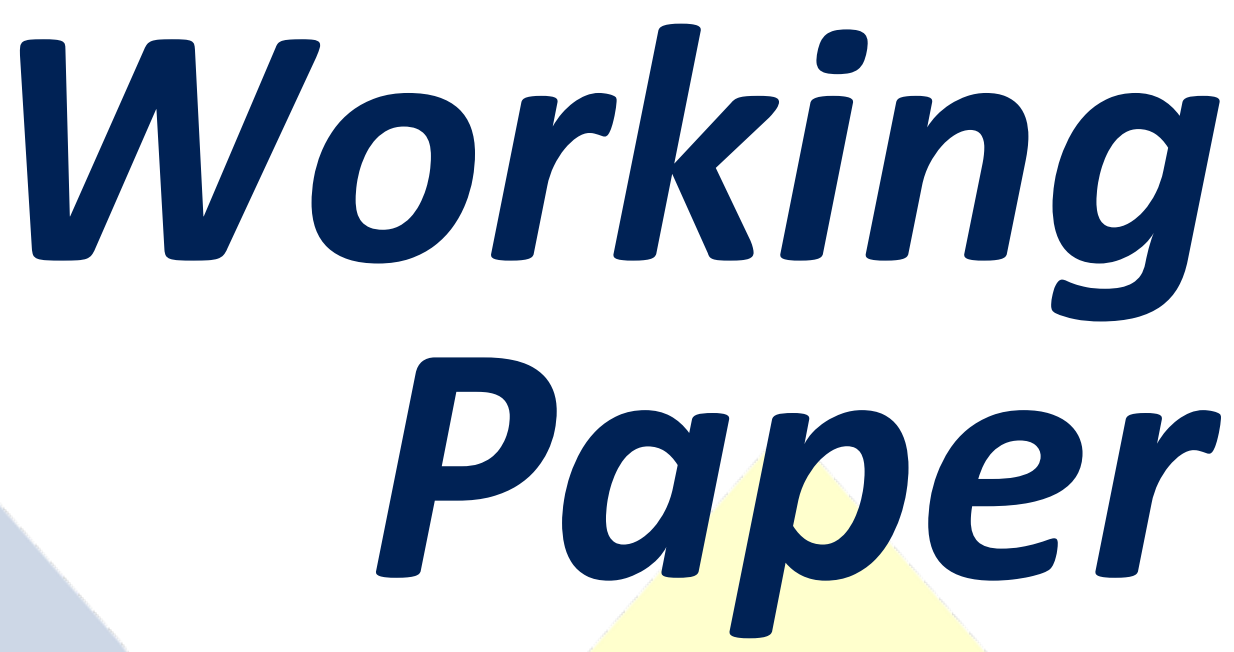

Numero 6/2018

Does the construction of biogas plants affect local property values?

Marco Modica 


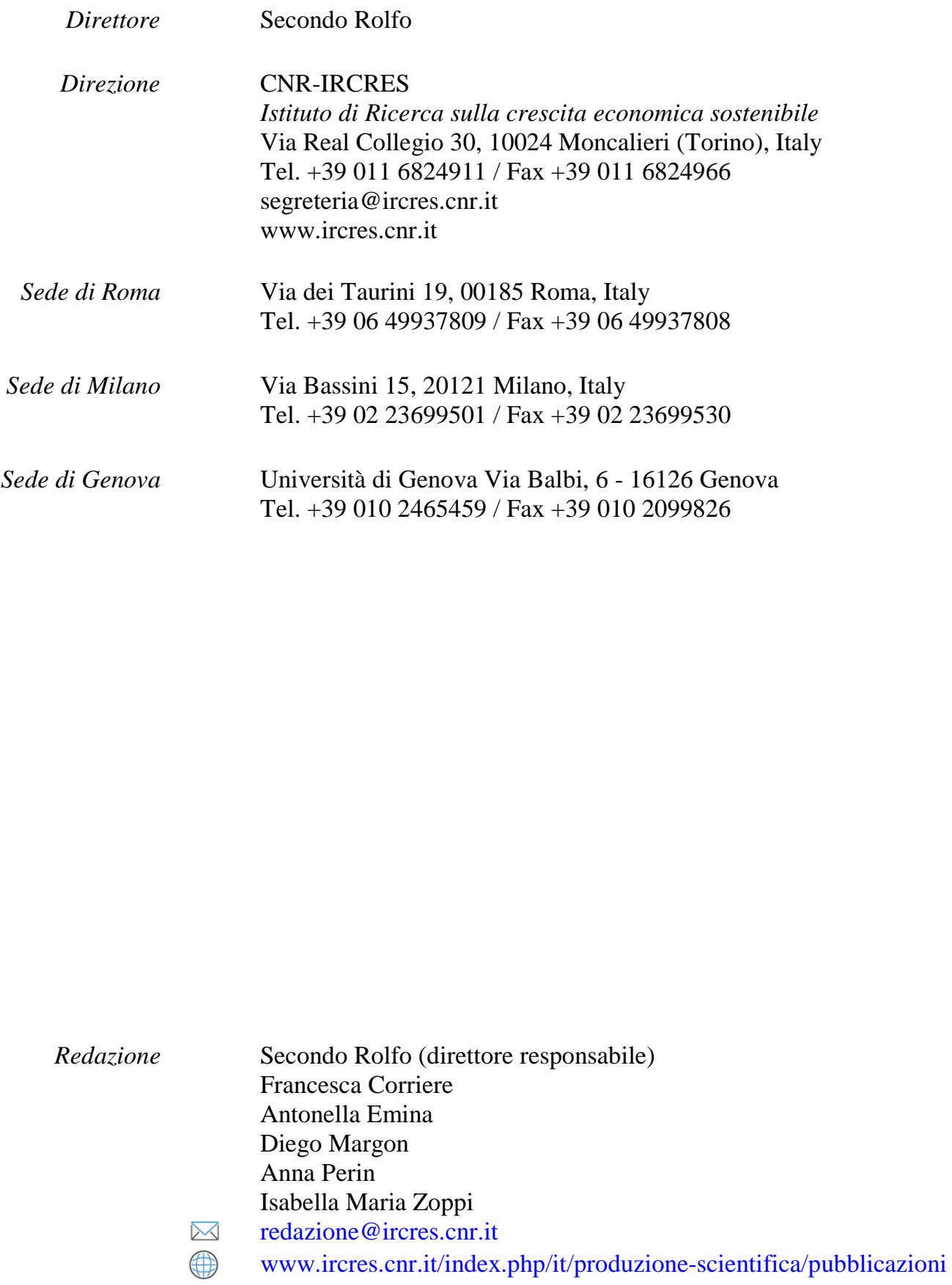

WORKING PAPER CNR-IRCRES, anno 4, numero 6, agosto 2018

(c) (†) (9) Copyright (Cagosto 2018 by CNR - IRCRES 


\title{
Does the construction of biogas plants affect local property values?
}

\author{
MARCO MODICA
}

GSSI - Gran Sasso Science Institute, Viale F. Crispi, 7, 67100 L’Aquila - Italy

CNR-IRCRES, National Research Council, Research Institute on Sustainable Economic Growth, via Corti, 12, 20133 Milan Italy

corresponding author: marco.modica@ircres.cnr.it

\section{ABSTRACT}

Although biogas is considered a renewable source of energy, the social acceptability of biogas plants is controversial due to resistance from local communities who are afraid of potential local negative externalities. This paper aims to investigate this claim, by means of a diff-in-diff model, using evidence from the housing market of Piedmont, where 167 biogas plants were opened between 2006 and 2015. The results show no significant impact of the opening of a biogas plant on housing values in neighboring areas.

KEYWORDS

Urban housing market; biogas plant; undesirable facilities; quasi-experiment.

JEL CODES: O18, Q42, Q51, R31

DOI: $10.23760 / 2421-7158.2018 .006$

Modica M., 2018. Does the construction of biogas plants affect local property values?, Working Paper IRCrES, 4(6). http://dx.doi.org/10.23760/2421-7158.2018.006 


\section{CONTENTS}

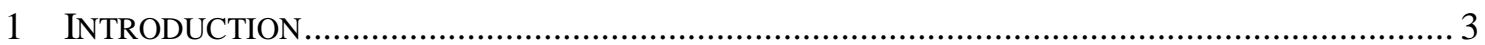

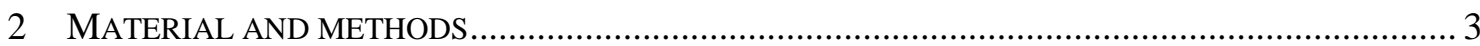

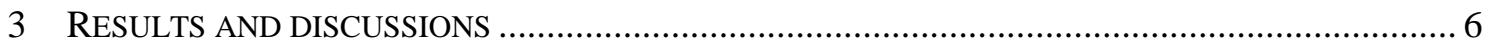

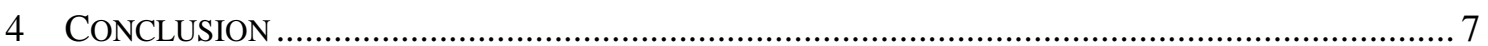

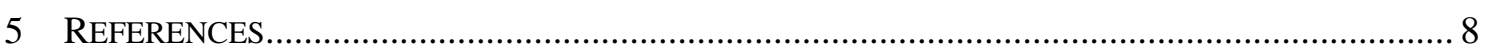




\title{
Does the construction of biogas plants affect local property values?
}

\author{
MARCO ModicA
}

\section{INTRODUCTION}

Italy is a country where a huge amount of energy is produced from biogas, and consists of 1,224 biogas plants, resulting in $947 \mathrm{MW}$ installed power (15\% of the total energy produced by renewables in Italy: GSE, 2016). However, the social acceptability of biogas plants is controversial due to resistance from local communities, because of potential local negative externalities, including smell, heavy traffic, and noise.

To evaluate this claim, the paper uses evidence from the housing market in Piedmont. Halfyearly average housing prices at the sub-municipal level are analyzed using a diff-in-diff model. The identification strategy involves the location of 167 biogas plants that opened in Piedmont between 2006 and 2015. In general, the results show no difference in the average level of house prices in the area where biogas plants are located as compared with house prices in other parts of the region ${ }^{1}$.

As far as is known to the author, this is the first paper which aims to evaluate the impact on house prices of the opening of biogas plants. However, it should be noted that dozens of studies have used residential housing market data to estimate the impact of locally-undesirable facilities on house prices (Davis, 2011; Gamper-Rabindran and Timmins, 2013; Greenstone and Gallagher, 2008; Grislain-Letrémy and Katossky, 2014; Ham et al., 2013; Kiel and Williams, 2007; Lang et al., 2014).

\section{MATERIAL AND METHODS}

The biogas plants data are provided by the Agency for Environmental Protection of Piedmont (ARPA-Piemonte), and they account for the location of 167 plants, their installed power, authorization and effective opening dates, and the presence of a CHP (combined-heat-and-power) unit.

The 'Italian Tax and Revenue Service' (Agenzia delle Entrate-Osservatorio del Mercato Immobiliare) provides information, derived from the actual transactions that take place in the market, on average prices for different housing units ("high-quality", "low-quality”, and "villas", i.e. single-family residential units). The scale of the analysis is at the sub-municipal level (e.g. segments of the local real-estate market that have uniform socio-economic and environmental conditions). The data cover the period 2006-2015 and are half-yearly.

The main empirical challenge in such a study is to construct an appropriate treated group and a suitable counterfactual for the locations where biogas plants have been opened. The strategy adopted is the following: the focus is on sub-municipal areas that have a biogas plant within a distance of $2 \mathrm{~km}$ from their centroid. This distance has been considered because odour nuisance

\footnotetext{
${ }^{1}$ The only exception being the impact on the price of low-quality houses of plants that have a CHP (combined-heat-and-power) unit.
} 
(proxy for noise from the biogas plant) can affect an area up to $2 \mathrm{~km}$ from the plant (see Skøtt, 2006). Then, a control group is provided by all the other homogeneous housing market areas that have no biogas plants nearby. The map in Figure 1 shows the treated and the control areas. Table 1 contains the descriptive statistics.

To examine pre-existing trends the following model was run:

$$
\log \left(\text { Price }_{i, j, t}\right)=\alpha_{i, j}+\sum_{t<2012} \tau_{t} D_{j} T_{t}+u_{i, j, t}
$$

where $\tau_{t}$ are the coefficients of the time dummies $\tau_{t}$.Then the joint significance of the estimated time-varying coefficients, $\tau_{t}$, of the treatment dummies before the treatment was tested. If the test does not reject the $H_{0}$, it can be affirmed that the two samples satisfy the common trend assumption.

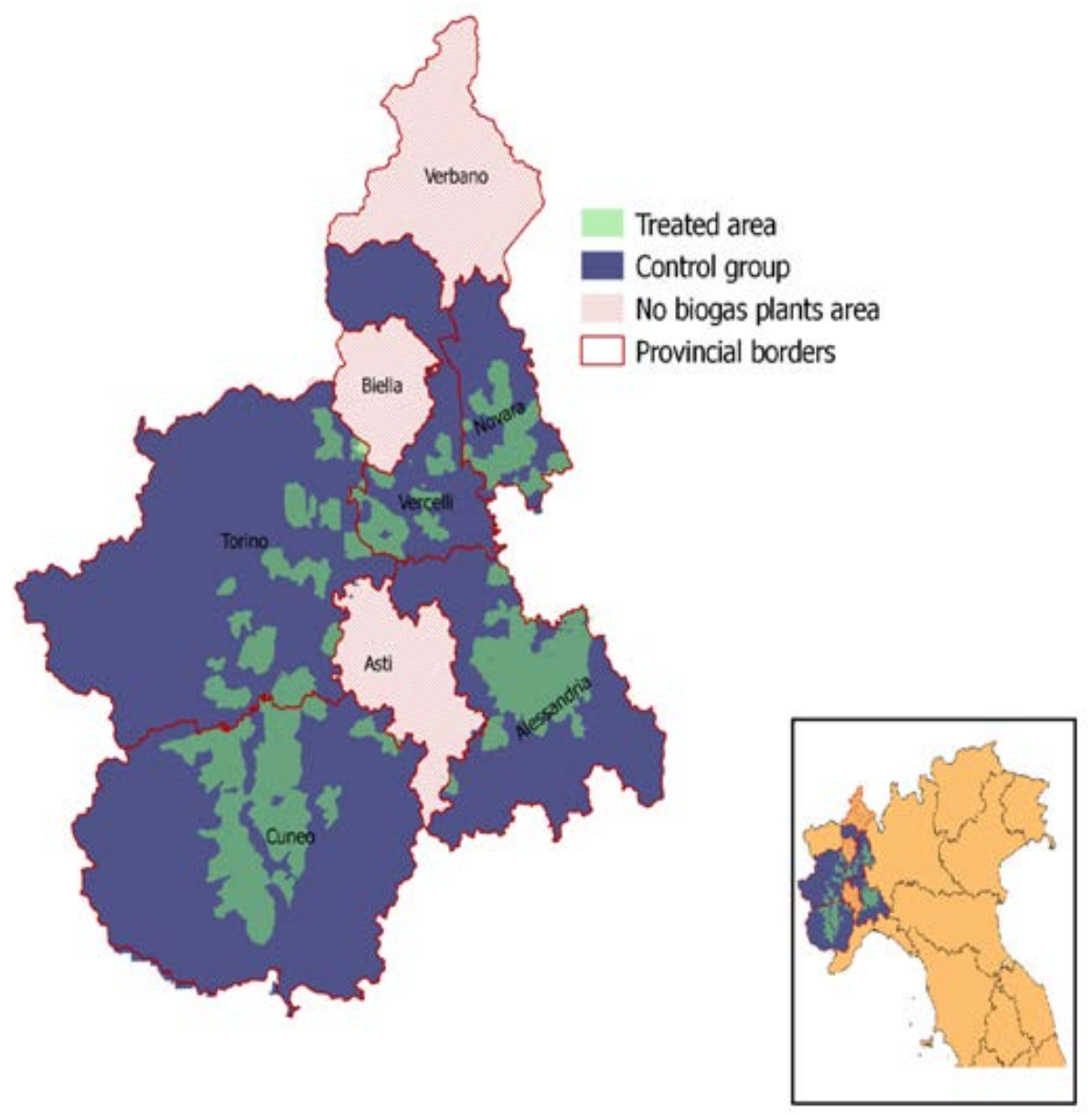

Figure 1. Study area 
Table1. Descriptive statistics

\begin{tabular}{|c|c|c|c|c|c|}
\hline Type of house & $\begin{array}{l}\text { No. } \\
\text { Observations }\end{array}$ & $\begin{array}{l}\text { Average } \\
\log \text { (price) }\end{array}$ & $\begin{array}{l}\text { Standard } \\
\text { deviation }\end{array}$ & Min & $\operatorname{Max}$ \\
\hline \multicolumn{6}{|l|}{ All sample } \\
\hline All types & 75,193 & 6.95 & 0.32 & 5.70 & 8.43 \\
\hline 'High-quality' house & 33,339 & 6.93 & 0.34 & 5.77 & 8.43 \\
\hline ‘Low-quality’ house & 18,776 & 6.84 & 0.30 & 5.70 & 8.16 \\
\hline Villa & 23,078 & 7.05 & 0.26 & 6.21 & 8.27 \\
\hline \multicolumn{6}{|l|}{ Treated-Area } \\
\hline All types & 10,065 & 6.95 & 0.26 & 5.76 & 7.61 \\
\hline ‘High-quality’ house & 4,444 & 6.93 & 0.29 & 5.77 & 7.61 \\
\hline ‘Low-quality’ house & 2,550 & 6.87 & 0.24 & 6.07 & 7.50 \\
\hline Villa & 3,071 & 7.03 & 0.21 & 6.21 & 7.60 \\
\hline \multicolumn{6}{|l|}{ Control-Area } \\
\hline All types & 65,128 & 6.95 & 0.32 & 5.70 & 8.42 \\
\hline 'High-quality' house & 28,895 & 6.93 & 0.34 & 5.81 & 8.43 \\
\hline ‘Low-quality’ house & 16,226 & 6.83 & 0.31 & 5.70 & 8.16 \\
\hline Villa & 20,007 & 7.05 & 0.26 & 6.21 & 8.23 \\
\hline
\end{tabular}

Table 2 provides evidence for the acceptability of the common trend assumption for all the selected samples (e.g. selection of the plant by authorization or opening date and types of housing).

Table 2. Pre-treatment common test

\begin{tabular}{lcccc}
\hline \multirow{2}{*}{ Sample } & \multicolumn{2}{c}{ Authorization date } & \multicolumn{2}{c}{ Opening Date } \\
\cline { 2 - 5 } & F test & p-value & F test & p-value \\
\hline All observations & 0.97 & 0.51 & 1.64 & 0.32 \\
High-quality housing & 2.43 & 0.20 & 2.33 & 0.22 \\
Low-quality housing & 7.53 & 0.06 & 1.21 & 0.44 \\
Villa & 2.30 & 0.22 & 3.54 & 0.12 \\
\hline
\end{tabular}

Given the results provided in Table 2, it is possible to evaluate the market response to the opening of a biogas plant. A standard diff-in-diff model is used as follows:

$$
\log \left(\text { Price }_{i, j, t}\right)=\alpha_{i, j}+\beta_{1} D_{j}+\beta_{2} D_{j} * \text { Post }_{j t}+\text { yeardummy }+\gamma X_{j, t}^{\prime}+u_{i, j, t},
$$

where the dependent variable is the $\log$ of the average price of the housing unit, $i$, in the submunicipal area, $j$, at time $t ; D$ is a dummy variable equal to 1 if the observation is in the treatment groups, and 0 otherwise; Post is a dummy that assumes the value 1 if the treatment occurs, and 0 otherwise. $X_{j, t}^{\prime}$, is a set of dummies able to capture the characteristics of specific biogas plants, 
such as Size (a variable which assumes the value 1 if the installed power is higher than $1 \mathrm{Mw}$ ), CHP (presence of a CHP unit), and Multiple Plants (more than one plant). A time fixed effect model is used.

As argued by Bertrand et al. (2004), in standard diff-in-diff setting, serial correlation might be an issue because it leads to inconsistent smaller standard errors (i.e. overestimation of the significance level of $\hat{\beta}_{\mathrm{i}}$ ) for three reasons: 1 ) there are long time periods; 2 ) there is positive serial correlation in the housing prices (see Glaeser et al., 2014); and 3) the treatment variable (Post in Equation 2) changes very little over time. Consequently, in order to avoid serial correlation, block bootstrap with 500 replications was run, by clustering all the observations that belong to the same province. Indeed Bertrand et al., 2004 prove that simple parametric corrections show a lower performance if compared with block bootstrap. In brief, block bootstrap is a technique that enables random blocks of individual units to be created in order to maintain the autocorrelation structure of the data so that it is not broken up by the classical bootstrap procedure (MacKinnon, 2006).

\section{RESULTS AND DISCUSSIONS}

Several models was run in order to take into consideration the differences in house prices that may arise between the date of the authorization to build a biogas plant (Table 3) and the effective date of the opening (Table 4). A differentiation was also made for the type of housing ("highquality", "low-quality", and "villa") in order to account for possible differences in the relative perception of the opening of a biogas plant (e.g. people who lives in "high-quality" houses might be more susceptible than others to the opening of a biogas plant in the neighboring area). The results are shown both with and without specific biogas plant characteristics (e.g. the size of the plant measured in terms of its power capacity, the presence of a CHP unit and the presence of more than one plant in the neighboring area) to control for the possibility that selected biogas plants characteristics might affect house prices.

Table 3 provides the results in relation to the impact on the house market of the biogas plant authorization. The results are not significant in all cases. Similar results are obtained when looking at the impact of the opening date, the only exception being a slightly negative and significant effect (lower than 1\%) on low-quality houses of plants that have a CHP. However, generally, the results show the non significant impact on the housing market of the presence of a biogas plant in urbanized areas. 
Table 3. Diff-in-diff by type of residential buildings (by date of authorization of the biogas plant)

\begin{tabular}{|c|c|c|c|c|c|c|c|c|}
\hline \multirow[t]{3}{*}{ Independent variable } & \multicolumn{8}{|c|}{ log of the average price } \\
\hline & \multicolumn{2}{|c|}{ All residential units } & \multicolumn{2}{|c|}{ "High-quality houses" } & \multicolumn{2}{|c|}{ "Low-quality houses" } & \multicolumn{2}{|c|}{ "Villas" } \\
\hline & (1) & (2) & (3) & (4) & (5) & (6) & (7) & (8) \\
\hline \multirow[t]{2}{*}{ Constant } & $6.909 * * *$ & $6.909 * * *$ & $6.876^{* * *}$ & $6.876^{* * *}$ & $6.805^{* * *}$ & $6.806 * * *$ & $7.040^{* * *}$ & $7.040 * * *$ \\
\hline & $(0.0503)$ & $(0.0504)$ & $(0.0823)$ & $(0.0823)$ & $(0.0465)$ & $(0.0461)$ & $(0.0485)$ & $(0.0486)$ \\
\hline \multirow[t]{2}{*}{ Interaction $(\beta 2)$} & 0.00323 & 0.00204 & 0.000938 & -0.000300 & 0.00342 & 0.00474 & 0.00678 & 0.00364 \\
\hline & $(0.00997)$ & $(0.00699)$ & $(0.0113)$ & $(0.0102)$ & $(0.0105)$ & $(0.00407)$ & $(0.0110)$ & (0.00559) \\
\hline \multirow[t]{2}{*}{ Size } & & 0.00223 & & 0.00235 & & -0.0291 & & 0.0294 \\
\hline & & $(0.0446)$ & & $(0.0361)$ & & $(0.0737)$ & & $(0.0431)$ \\
\hline \multirow[t]{2}{*}{ CHP } & & -0.00844 & & -0.00657 & & -0.00917 & & -0.0102 \\
\hline & & $(0.00673)$ & & $(0.00973)$ & & $(0.00563)$ & & $(0.0141)$ \\
\hline \multirow[t]{2}{*}{ Multiple plants } & & 0.0354 & & 0.0315 & & 0.0506 & & 0.0232 \\
\hline & & $(0.0295)$ & & $(0.0163)$ & & $(0.0569)$ & & $(0.0288)$ \\
\hline Time dummies & YES & YES & YES & YES & YES & YES & YES & YES \\
\hline $\mathrm{R} 2$ & 0.116 & 0.118 & 0.118 & 0.118 & 0.172 & 0.174 & 0.0992 & 0.102 \\
\hline $\mathrm{N}$ & 75193 & 75193 & 33339 & 33339 & 18776 & 18776 & 23078 & 23078 \\
\hline
\end{tabular}

${ }^{*} \mathrm{p}<0.1,{ }^{* *} \mathrm{p}<0.05,{ }^{* * *} \mathrm{p}<0.01$. Block-bootstrap standard errors in parentheses

Table 4. Diff-in-diff by type of residential buildings (by opening date of the biogas plant)

\begin{tabular}{|c|c|c|c|c|c|c|c|c|}
\hline \multirow[t]{3}{*}{ Independent variable } & \multicolumn{8}{|c|}{$\log$ of the average price } \\
\hline & \multicolumn{2}{|c|}{ All residential units } & \multicolumn{2}{|c|}{ "High-quality houses" } & \multicolumn{2}{|c|}{ “Low-quality houses" } & \multicolumn{2}{|c|}{ Villas } \\
\hline & (9) & $(10)$ & $(11)$ & $(12)$ & $(13)$ & $(14)$ & $(15)$ & $(16)$ \\
\hline \multirow[t]{2}{*}{ Constant } & $6.909 * * *$ & $6.909 * * *$ & $6.876^{* * *}$ & $6.876^{* * *}$ & $6.805^{* * *}$ & $6.806 * * *$ & $7.040 * * *$ & $7.040 * * *$ \\
\hline & $(0.0503)$ & $(0.0504)$ & $(0.0823)$ & $(0.0823)$ & $(0.0465)$ & $(0.0461)$ & $(0.0485)$ & $(0.0486)$ \\
\hline \multirow[t]{2}{*}{ Interaction $(\beta 2)$} & 0.00329 & 0.00205 & 0.00131 & 0.000907 & 0.00423 & 0.00471 & 0.00544 & 0.00150 \\
\hline & $(0.00804)$ & $(0.00419)$ & $(0.00871)$ & $(0.00579)$ & $(0.0126)$ & $(0.00411)$ & $(0.00813)$ & $(0.00511)$ \\
\hline \multirow[t]{2}{*}{ Size } & & 0.00520 & & 0.0101 & & -0.0225 & & 0.0226 \\
\hline & & $(0.0397)$ & & $(0.0322)$ & & $(0.0736)$ & & $(0.0328)$ \\
\hline \multirow[t]{2}{*}{ CHP } & & -0.00931 & & -0.0102 & & $-0.00978 * *$ & & -0.00738 \\
\hline & & $(0.00571)$ & & $(0.00871)$ & & $(0.00408)$ & & $(0.0141)$ \\
\hline \multirow[t]{2}{*}{ Multiple plants } & & 0.0323 & & 0.0262 & & 0.0508 & & 0.0220 \\
\hline & & $(0.0301)$ & & $(0.0180)$ & & $(0.0599)$ & & $(0.0263)$ \\
\hline Time dummies & YES & YES & YES & YES & YES & YES & YES & YES \\
\hline R2 & 0.116 & 0.118 & 0.118 & 0.118 & 0.172 & 0.174 & 0.0991 & 0.101 \\
\hline $\mathrm{N}$ & 75193 & 75193 & 33339 & 33339 & 18776 & 18776 & 23078 & 23078 \\
\hline
\end{tabular}




\section{CONCLUSION}

The production of biogas is a complex and variegated activity and despite the possible positive environmental effect on local areas, potential local negative externalities stemming from biogas plants can even affect house prices in the areas nearby plants. However, after analyzing 167 biogas plants which opened in Piedmont between 2006 and 2015, this paper has provided no evidence of such a claim in that particular area. The opening of biogas plants has had no effect on house prices.

ACKNOWLEDGEMENTS: A more extensive version of the work was developed for the H2020 research project - ISAAC. The present version of the paper was accepted for publication in Economics Letters.

\section{REFERENCES}

Bertrand, M., Duflo E., Mullainathan S. (2004). How Much Should We Trust Differences-inDifferences Estimates? The Quarterly Journal of Economics, 119: 249-275.

Davis, LW. (2011). The effect of power plants on local housing values and rents. Review of Economics and Statistics, 93(4): 1391-1402.

Gamper-Rabindran, S., Timmins, C. (2013). Does cleanup of hazardous waste sites raise housing values? Evidence of spatially localized benefits. Journal of Environmental Economics and Management, 65(3): 345-360.

Glaeser, EL., Gyourko, J., Morales, E., Nathanson, CG. (2014). Housing dynamics: An urban approach. Journal of Urban Economics, 81:45-56.

Greenstone, M., Gallagher, J. (2008). Does hazardous waste matter? Evidence from the housing market and the superfund program. The Quarterly Journal of Economics, 123(3): 951-1003.

Grislain-Letrémy, C., Katossky, A. (2014). The impact of hazardous industrial facilities on housing prices: A comparison of parametric and semiparametric hedonic price models. Regional Science and Urban Economics, 49: 93-107.

GSE (2016). Incentivazione delle fonti rinnovabili. Retrieved at http://www.gse.it

Ham, YJ., Maddison, DJ., Elliott, RJ. (2013). The valuation of landfill disamenities in Birmingham. Ecological Economics, 85:116-129.

Kiel, K.A., Williams, M. (2007). The impact of superfund sites on local property values: Are all sites the same? Journal of Urban Economics, 61(1): 170-192.

Lang, C., Opaluch, JJ., Sfinarolakis, G. (2014). The windy city: Property value impacts of wind turbines in an urban setting. Energy Economics, 44: 413-421.

MacKinnon, J.G. (2006). Bootstrap methods in econometrics. Economic Record, 82(s1): S2-S18

Skøtt, T. (2006). How much do biogas plants smell? Bioenergy Research, 16: 4-5. 